\title{
Consultant psychiatrists' opinions and experience of CPD
}

\author{
Chris Williams, Andrew Sims and Tom Sensky
}

\begin{abstract}
A postal survey was carried out on a random sample of Fellows and Members of the Royal College of Poychiatrists in the United Kingdom or Eire in order to investigate current Continuing Professional Development (CPD) practice and the impact of resources and funding for CPD. One hundred and thirteen of 264 anonymised questionnaires were retumed (43\%). Most respondents considered CPD should be mandatory for consultants, for educational supervisors, for ellgiblility for the Certificate of Completion of Speciallist Training and for election to the Fellowship of the College.
\end{abstract}

Formal but voluntary certification of Continuing Professional Development (CPD) for psychiatrists was implemented by the Royal College of Psychiatrists in January 1995 (Sims 1994, 1995). By January 1997 more than half of the consultant psychiatrists in the United Kingdom had registered.

A previous College survey of what was then termed Continuing Medical Education (CME) was carried out by T. S. and others in 1993 (Sensky, 1994). The purpose of the current study is to investigate current attitudes and practical experience of CPD by trained psychiatrists, and to explore potential difficulties that prevent the uptake of CPD and to assess progress with CPD since the earlier study.

\section{The study and findings}

The sample for this survey comprised a one in 10 random sample of Members of the Royal College of Psychiatrists who were consultants in the United Kingdom and Eire. Two hundred and sixty-four anonymised questionnaires were sent out in April, 1996; 113 had been returned by June, 1996 (43\%). The questionnaire was based on a shortened version of the earlier College questionnaire. Analysis of the results evaluated access to local CPD resources and facilities, work and personal issues relevant to CPD and funding issues affecting the ability to attend CPD events.

The mean age of respondents was 47.4 (range 34-69) with 82 men (73\%) and 31 women (27\%). Eighty-three (74\%) were Members and 29 (26\%) were Fellows of the College. Ninety-five per cent of respondents worked as National Health Service (NHS) consultants. Most (50\%) worked in general adult psychiatry, $19 \%$ in child and adolescent, $11 \%$ in old age, $6 \%$ in learning disability and the remainder working in substance misuse (5\%), forensic psychiatry (4\%), psychotherapy $(2 \%)$, rehabilitation $(2 \%)$ and liaison psychiatry (1\%).

\section{Resources for CPD}

Fifty-five per cent had been to their local medical library in the previous week and $75 \%$ in the previous month. In the original 1993 survey (Sensky, 1994), 69\% had access to a medical library on site. This had increased to $78 \%$ in the current survey. Twenty-three per cent had to travel more than 10 miles to a library. Only 23\% stated that their CPD was hindered by a lack of library facilities. There are some clear differences with 1993. The survey then showed that $68 \%$ of consultants could obtain items free of charge. while only $52 \%$ could now. In 1993 , only $3 \%$ of consultants had to pay a pound or more to order photocopies or books but this has now risen to $30 \%$.

The two most popular journals, scoring a median response as 'very good' or 'excellent' on measures of both increasing knowledge and increasing clinical skills, are Advances in Psychiatric Treatment and Current Opinion in Psychiatry. The BritishJournal of Psychiatry was rated as being very good/good' for increasing knowledge and as 'reasonable' for increasing skills.

\section{Literature searching and access to electronic} literature sources

Fifty-two per cent use CD-ROM search facilities in a library. More respondents now have access to a computer at work (61\%) than in $1993(56 \%)$. In addition, $17 \%$ now have their own e-mail address and $15 \%$ have access to the Internet. In spite of the fact that $51 \%$ had a home computer, only $19 \%$ of these doctors carried out literature searches from home. 
Attendance at local educational meetings

The majority had attended a case conference (87\%), journal club $(63 \%)$ and audit meeting $(66 \%)$ in the last month. In 1993 , only $5 \%$ of consultants had failed to attend any such local CPD activities and $60 \%$ had attended four or more such activities. In the current survey, only $43 \%$ had attended four or more types of meeting during the last month. Those with a senior registrar were more likely to attend local case conferences $\left(\chi^{2}=3.68,1\right.$ d.f., $\left.P=0.054\right)$ and local research meetings $\left(\chi^{2}=8.08,1\right.$ d.f., $\left.P=0.0045\right)$.

\section{Attendance at nationally advertised and} College meetings

The majority of psychiatrists (62\%) had attended a nationally advertised training course or workshop in the last year and $12 \%$ had attended nationally advertised conferences abroad, $61 \%$ had attended a meeting organised by a pharmaceutical company and $34 \%$ had received funding from a drug company to attend a postgraduate meeting in the last year. This figure was almost identical to the $35 \%$ who received such funding in 1993.

\section{Funding and practical blocks to CPD}

The main reasons given by doctors for failing to attend postgraduate meetings are listed in Table 1.

One important area identified by between 38 and $47 \%$ of respondents was that they perceived the content of meetings to be unattractive. This was particularly so at locally organised events, and less so at regional and national events. The most popular teaching styles were small groupbased work, lecture-based teaching, one-day non-residential and several day residential courses all of which received a median rating of 'moderately useful'.

Impact of access to local facilities and study leave funding for $C P D$

One of the most important facilities that affects CPD, however, is access to local NHS funding for study leave. In 1993, $71 \%$ of consultants were able to obtain NHS study leave to attend postgraduate meetings. This increased to $77 \%$ in 1996, but this still implies that $23 \%$ were not able to obtain NHS funded study leave. Sixty-two per cent of consultants reported that availability of funding for CPD was limited; $50 \%$ had to contribute to study leave from their own pocket and this had increased from 44\% in 1993. Twenty-eight stated that they had decided not to attend CPD or other educational events as a result of limited funding for study leave. More consultants now do not attend CPD events as a result of a failure to obtain study leave than in 1993. Finally, those consultants who are based in settings where study leave is made available are also more likely to attend local CPD events as well.

\section{The role of the College in $C P D$}

A major recent innovation by the College is the introduction of voluntary, formal CPD certification: $50 \%$ had registered for this and $55 \%$ received Advances in Psychiatric Treatment. Of those replying on this item $(n=74)$, only $7 \%$ found that journal poor or very poor and $73 \%$ rated the journal as either useful or very useful. Forty per cent of those who received Advances in Psychiatric Treatment, also attended the Annual College Meeting. This compares with only $18 \%$ of those

Table 1. Reasons for not attending postgraduate training meetings

\begin{tabular}{|c|c|c|c|c|}
\hline $\begin{array}{l}\text { Causing problems } \\
\text { in attending }\end{array}$ & $\begin{array}{l}\text { Local } \\
\text { meetings, } \\
n(\%)\end{array}$ & $\begin{array}{l}\text { Regional } \\
\text { meetings, } \\
n(\%)\end{array}$ & $\begin{array}{l}\text { National } \\
\text { meetings, } \\
n(\%)\end{array}$ & $\begin{array}{l}\text { Response in } \\
1993 \text { College } \\
\text { survey }\end{array}$ \\
\hline $\begin{array}{l}\text { Not enough time } \\
\text { Content } \\
\text { Time of the meetings } \\
\text { Inadequate consultant cover } \\
\text { at your base }\end{array}$ & $\begin{array}{l}78(69) \\
53(47) \\
49(43) \\
43(38)\end{array}$ & $\begin{array}{l}83(74) \\
49(43) \\
53(47) \\
53(47)\end{array}$ & $\begin{array}{l}83(74) \\
43(38) \\
40(35) \\
59(52)\end{array}$ & $\begin{array}{l}\text { NA } \\
78 \% \\
80 \% \\
54 \%\end{array}$ \\
\hline $\begin{array}{l}\text { Inadequate junior cover } \\
\text { at your base }\end{array}$ & $39(35)$ & $42(37)$ & $43(38)$ & $40 \%$ \\
\hline $\begin{array}{l}\text { Not enough notice given } \\
\text { Lack of own interest }\end{array}$ & $\begin{array}{l}36(32) \\
17(15)\end{array}$ & $\begin{array}{l}34(30) \\
21(19)\end{array}$ & $\begin{array}{l}23(20) \\
16(14)\end{array}$ & $\begin{array}{l}\text { NA } \\
\text { NA }\end{array}$ \\
\hline $\begin{array}{l}\text { Cost/failure to get paid } \\
\text { study leave }\end{array}$ & $16(14)$ & $22(20)$ & $32(28)$ & $18 \%$ \\
\hline Distance & $9(8)$ & $44(39)$ & $72(64)$ & $80 \%$ \\
\hline $\begin{array}{l}\text { Feel I have no real needs } \\
\text { for training }\end{array}$ & $5(4)$ & $4(4)$ & $3(3)$ & NA \\
\hline
\end{tabular}

NA direct comparison not possible with 1993 survey. 
who do not receive the journal $\left(\chi^{2}=6.52,1\right.$ d.f., $P<0.01$ ).

Fifty-three per cent of respondents believed that the College should make CPD mandatory and $60 \%$ believed that there should be regular audit of each individual's participation in CPD (57\% in 1993). Fifty per cent considered that CPD activity should be mandatory for the award of Fellowship and $27 \%$ believed that Fellowship should be removed from those who do not seek out CPD; $61 \%$ felt that the training posts should be removed from those who fail to continue with CPD.

\section{Comment}

The response rate of $43 \%$ is low. There is a risk of bias as a result of the self-selection of respondents who may be more disposed towards CPD than those who failed to respond. Effective local support for CPD is crucial. Access to information sources is one practical component of this support; although access to medical libraries has improved since 1993, it is disconcerting that more consultants are having to pay for papers not held in the library and the cost of obtaining materials is increasing. It seems inappropriate that at a time when CPD and evidence-based medicine is being encouraged, the direct costs of carrying out personal CPD are also being increased.

Shortage of time and dissatisfaction with content were the main barriers to attending meetings. In general, there were no strong preferences for the format of educational activities. Being involved in medical training was a key factor affecting participation in CPD.

\section{Where next for CPD?}

The funding of CPD presents major difficulties for the individual consultant and also their employing authority. The survey has implications for trusts, individual consultants and the College. There is a need for consultants to take responsibility for their own professional further training. This must be encouraged actively by trusts in a number of ways: (a) By providing financial support. It is unreasonable to expect consultants to fund CPD out of their own pockets, even if this practice is currently widespread.

(b) Contracts and job plans should specify identified time and resources for CPD. Specific time could be identified in job plans to allow local CPD, and CPD should be a central part of personal/professional development plans.

The College can play an important role in alerting trusts to the importance of high-quality CPD. This is likely to lead to benefits both for the individual consultants, their patients and the employing authority.

\section{Acknowledgements}

We are very grateful to Pauline Taggart, David Hills and Liz Atkinson of the CPD Department of the College for their hard work in carrying out and administering the survey.

\section{References}

Sims, A. C. P. (1994) Introducing Continuing Professional Development. Advances in Psychiatric Treatment, 1, 1-8.

- (1995) Continuing Professional Development in psychiatry. In Management for Psychiatrists (2nd edn) (eds D. Bhugra \& A. Burns), pp. 317-325. London: Gaskell.

SENSKY, T. (1994) Continuing medical education: consultant psychiatrists' experience and opinions. Psychiatric Bulletin, 18, 18-22.

*C. J. Williams, Senior Lecturer in Psychiatry. University of Leeds Division of Psychiatry, CSB, St James's University Hospital, Leeds, LS9 TTF, A. C. P. Sims, Professor of Psychiatry and Director of Continuing Professional Development, Royal College of Psychiatrists, and T. Sensky, Reader in Psychological Medicine, West Middlesex University Hospital, Isleworth, Middlesex TW7 6AF

*Correspondence 